


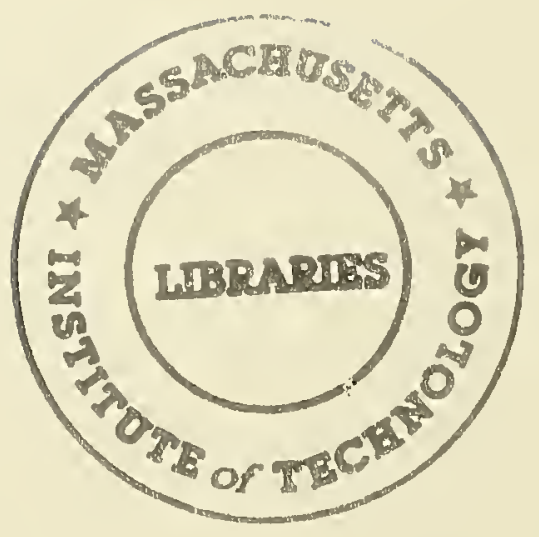





\section{Digitized by the Internet Archive in 2011 with funding from}

Boston Library Consortium Member Libraries 
HB 31

.9415

$120.95-26$

\section{working paper department of economics}

TWO VIEWS OF THE BRITISH INDUSTRIAL REVOLUTION

\section{Peter Temin}

\section{massachusetts institute of technology}

50 memorial drive cambridge, mass. 02139 


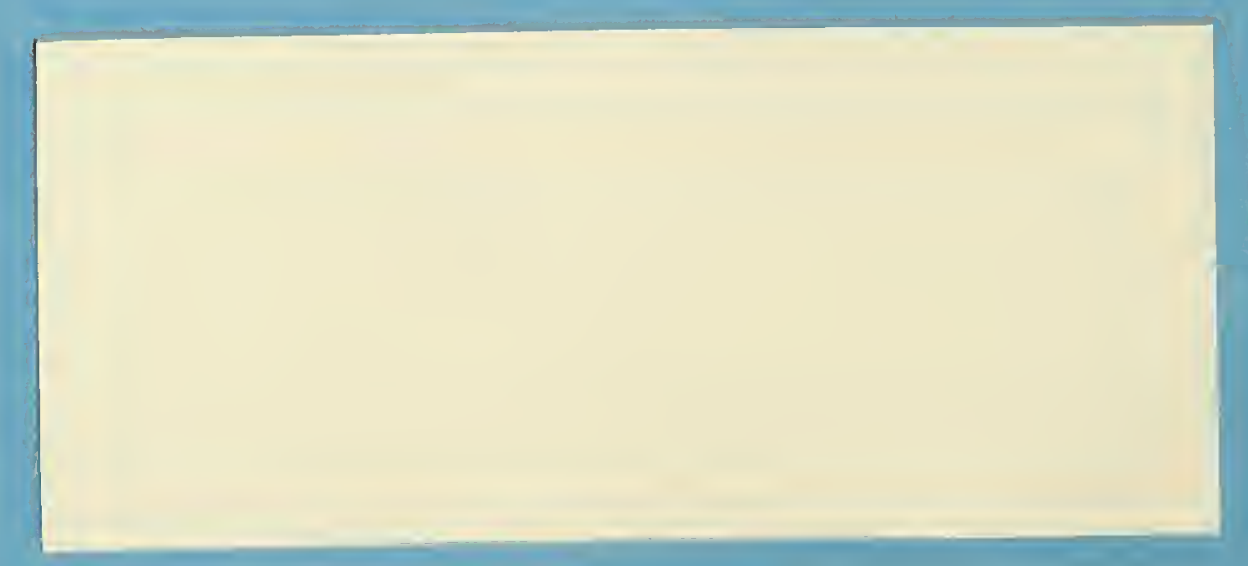


TWO VIEWS OF THE BRITISH INDUSTRIAL REVOLUTION

Peter Temin

95-26

Oct. 1995 
MHASSACHUSCTIS MSTITUT

नी

Mru 141995 


\title{
Two Views of the British Industrial Revolution
}

\author{
Peter Temin
}

\section{M.I.T.}

October 27, 1995

I thank Wilson W. Tai for research assistance. 

Two Views of the British Industrial Revolution

Abstract

There are two views of the British Industrial Revolution in the literature today. The more traditional description, represented by the views of Ashton and Landes, sees the Industrial Revolution as a broad change in the British economy and society. This broad view of the Industrial Revolution has been challenged by Crafts and Harley who see the Industrial Revolution as a much narrower phenomenon, as the result of technical change in a few industries.

This paper presents a test of these views using the Ricardian model of international trade with many goods. British trade data are used to implement the test and discriminate between the two views of the Industrial Revolution. 

Two Views of the British Industrial Revolution

There are two views of the British Industrial Revolution in the literature today. The more traditional description is represented by the views of Ashton and Landes. It sees the Industrial Revolution as a broad change in the British economy and society. In Ashton's memorable phrase, "A wave of gadgets swept of England."1 This broad view of the Industrial Revolution has been challenged recently by Crafts and Harley. This new school of thought sees the Industrial Revolution as a much narrower phenomenon, as the result of technical change in a few industries. The new industries, obviously, were cotton and iron. All others were mired in pre-modern backwardness. ${ }^{2}$

It may seem as if the choice between these two views is a matter of taste, since the literature is almost exclusively about the two modern industries singled out by the narrow view of the Industrial Revolution. That appears to be how this choice is treated in the literature. In fact, the looseness of our current conception has encouraged a few people to take the views of Crafts and Harley to the extreme. Cameron argues that the changes noted by these authors was so small relative to the whole economy that it no longer deserves the title of Industrial Revolution. ${ }^{3}$

But it is seldom that an empirical question cannot be tested. True, productivity indexes are hard to calculate for obscure industries. It is necessary to search for other data 
that will let the historian discriminate between these two views. Trade data provide the information needed to discriminate between these two views.

I will use a Ricardian model of international trade to formulate a testable hypothesis about the nature of the Industrial Revolution. In this model, the traditional view of the Industrial Revolution implies that Britain should have been exporting other manufactures--that is, manufactured products other than cotton textiles and iron bars. In the more modern view, by contrast, Britain should have been importing these same goods in the early nineteenth century. Trade data allow us to see which is the case.

The plan of this paper is as follows. The first section argues that there are two distinct views of the Industrial Revolution in the literature. It will contrast the two views, showing how the divergent approaches have generated subsidiary disputes. The next section will describe the Ricardian model of international trade with many goods and formulate the hypothesis to be tested. The third section will describe the British trade data and implement the test of the previous section. A final section concludes.

\section{I}

The traditional view of the British Industrial Revolution can be found in countless texts. Ashton's exposition is still among the finest, and I will focus my description on it. Ashton clearly described a general change in British 
economy and society. He was very expansive in his descriptions of technical change: "Inventors, contrivers, industrialists, and entrepreneurs--it is not easy to distinguish one from another at a period of rapid change--came from every social class and from all parts of the country." Expanding the statement quoted above about "a wave of gadgets," Ashton said, "It was not only gadgets, however, but innovations of various kinds--in agriculture, transport, manufacture, trade, and finance--that surged up with a suddenness for which it is difficult to find a parallel at any other time or place."4

Ashton described the main venues of the Industrial Revolution: agriculture, coal mining, the iron industry, the textile industry. He then went on to highlight dramatic innovations in other activities, in the manufacture of pottery and in engineering. In his words: "The modern fitter, turner or pattern-maker can trace his pedigree back...to the millwright who was concerned with the creation and repair of water wheels and the grinding apparatus which they worked. He can find ancestors, moreover, in the colliery viewers, clock-makers, instrument-makers, ironfounders and cotton spinners, who, during the industrial revolution, turned from using to making the appliances of their trades." 5 To Ashton, change was hardly restricted to cotton and iron.

But even Ashton acknowledged that the technical changes of the Industrial Revolution did not extend evenly to all corners of the economy. The traditional view of the Industrial 
Revolution asserts that innovation was widespread, not universal. Industries affected were more than simply iron and cotton, but there existed many activities untouched by innovation in the period surveyed by Ashton, 1760-1830.6

This view was widespread during the $1950 \mathrm{~s}$ and $1960 \mathrm{~s}$. Landes expressed it well in a classic book. Acknowledging like Ashton that the Industrial Revolution began in the cotton industry, Landes asserted that "other branches of industry effected comparable advances." Landes seemed to anticipate the quantitative research of Crafts and Harley when he insisted that the change in these other industries was slow, but he argued that in the longer run, "the diffusion of mechanized manufacture called forth major improvements in tool design." "Because of the anonymity of many of these designs," Landes continued, "it is impossible to convey more than an approximate notion of the overall pace of advance." ?

Many monographs and texts were written at this time expressing this conception of the Industrial Revolution. Even if the innovations in many industries could not be identified, there was no doubt that they were there. The well-known growth estimates of Deane and Cole confirmed the view of widespread change and appeared to provide a firm basis for the qualitative expositions. ${ }^{8}$ More current work by Mokyr has supported the pervasiveness of technological change in Britain at this time. ${ }^{9}$

A recent survey of the literature labels this view, "oldhat" economic history. It "is still being read and continues to 
be written by an unrepentant but elderly generation of AngloAmerican economic historians," according to O'Brien. ${ }^{10}$ His exposition focused on the growth rate during the British Industrial Revolution, but estimates of income growth cannot be separated from the underlying conception of the Industrial Revolution, as shown below.

The growth rate of the British national product was adjusted downward in a gradual process. Harley revised the growth rate of manufacturing downward in 1982. Crafts extended these estimates into a revision of Deane and Cole's estimates of the British national product in his 1985 book. Crafts and Harley presented their "final" version in 1992. ${ }^{11}$

The implications of the new estimates for the conceptualization of the Industrial Revolution can be seen in an exercise introduced by McCloskey. ${ }^{12}$ He calculated the productivity gains of what he called the modernized sectors from industry sources. Then he weighted the gains by the share of the industries in gross production and added them. The productivity gain of all other sectors (except agriculture, which was estimated separately) was obtained by subtracting this total from the rate of growth of production in the economy as a whole. The calculations are shown in the first column of Table 1.

Crafts reproduced McCloskey's calculations in his book and noted that the bottom line, the estimated rate of growth of the economy as a whole, came from Deane and Cole. Since Crafts was 
revising these estimates, he substituted his new estimates as shown in the second column of Table 1. None of the industry estimates were changed; only the growth of the unidentified, residual sector. As can be seen, the contribution of "other sectors" to economic growth fell from .55 percent a year to 07 . In Crafts's words: "[T] he term 'Industrial Revolution'...should not be taken to imply a widespread, rapid growth of productivity in manufacturing. "13

Quite the contrary. As Crafts repeated throughout his discussion, the Industrial Revolution in this view was a decidedly localized affair. The industries affected were textiles, iron, and transportation. All else--other manufactures and other services--were technologically stagnant for the first half of the nineteenth century. This conclusion contrasts strongly with the assertions of Ashton and Landes.

Crafts has drawn several inferences from this view. One of the most controversial predates the new estimates of Britain's national product. In an early essay, crafts suggested that the Industrial Revolution might have occurred in France. While the odds favored Britain, the stochastic element in this event was large enough to make another outcome easily plausible. ${ }^{14}$

This heterodox view was startling then; it continues to arouse strong emotions today. David Landes took the occasion of his 1993 Tawney Lecture to blast Crafts for his by now ancient heresy. ${ }^{15}$ Crafts and Landes then had an interchange on the nature of history that generated more heat than light. ${ }^{16}$ High 
emotion in academic discourse usually signals the presence of disparate underlying conceptions. That is the case here.

As described above, Landes adheres to the traditional view of the Industrial Revolution in which economic change was widespread, albeit uneven. Crafts by contrast sees the Industrial Revolution as a change in a small number of industries. Crafts' revolution, being composed of only a few elements, could easily have been different. Landes' thoroughgoing revolution required society-wide preparation. This difference of viewpoints is obscured by Crafts' and Landes' focus--universal in this literature--on the cotton industry.

Other implications have proven less controversial. ${ }^{17}$ In the one most relevant here, Crafts confronted a paradox created by his new estimates: If British manufacturing was in general so backward and British agriculture so progressive--as we know from other sources--then why didn't Britain export agricultural goods and import manufactures in the early nineteenth century? ${ }^{18}$

It is important to understand the nature of this paradox. The traditional view implied that Britain had a comparative advantage in manufacturing. Even though British agriculture was very productive, possibly more productive than on the continent, it was comparative advantage that determined trade. And British industry was even more productive during the Industrial

Revolution than British agriculture. It was only natural that Britain should become the workshop of the world by the time of Crystal Palace. 
Crafts had denied the premise of this traditional view by asserting that most British manufacturing was backward and inefficient. The view that British agriculture was more productive than continental then implied that Britain had a comparative advantage in agriculture. It is no wonder that previous economic historians had not confronted this paradox; it does not exist in the traditional view of the Industrial Revolution.

The resolution of the paradox, Crafts responded, comes in two propositions. First, Crafts confirmed the existence of paradox by reiterating that most British industry "experienced low levels of labor productivity and slow productivity growth-it is possible that there was virtually no advance during 17801860." Second, he resolved the problem by asserting that "rapid growth in key manufacturing sectors...gave Britain a substantial comparative advantage in those activities."19 In other words, industrializing Britain had a comparative advantage in cotton and iron, not manufacturing as a whole.

The clear implication of Crafts' view is that other manufactures were not exported because Britain lacked a comparative advantage in manufacturing in general. In fact, the juxtaposition of evidence of a productive agriculture with that of stagnant manufacturing outside of textiles and iron provided evidence that Britain had a comparative disadvantage in these other manufactures. That is, Crafts' resolution of the paradox implies that Britain should have been importing other 
manufactures along with agricultural goods.

Crafts and Harley recently revised and restated their new views in light of the ensuing discussion. Their definitive views reduced the rate of economic growth during the Industrial Revolution even further than Crafts' initial estimates. ${ }^{20}$ Harley incorporated these estimates into McCloskey's exercise, as shown in the third column of Table 1. Harley revised McCloskey's estimates of productivity growth in the modern sector as Crafts had not done, reducing their aggregate contribution to economic growth. But because the rate of growth of the total economy was estimated to be so low, the contribution of other sectors fell to the vanishing point, from .07 percent per year to .02 .

These contributions are each sector's rate of productivity change weighted by its share of gross product. The data in the last column of Table 1 imply that the rate of productivity change in agriculture was .7 per year, while the rate of productivity change in the residual sector was .02 . If these rates are cumulated over the 80 years of the table, the backward sectors would have fallen very far behind agriculture--not to mention the modernized sector--by 1850 or $1860 .{ }^{21}$ In McCloskey's original calculation, the rate of productivity advance in all other activities was above the rate in agriculture. ${ }^{22}$

Harley also embedded the Crafts-Harley view into a computable general equilibrium model of the British economy in the early nineteenth century. He distinguished four producing sectors in Britain: modern manufacturing, agriculture, services, 
and other industry. (The latter two sectors are the "all other" sector of Table 1.) Britain exports the products of modern manufacturing and imports agricultural goods in this model; services and other manufactures are not traded. ${ }^{23}$

Harley asserted that this model demonstrates the consistency of the Crafts-Harley view. But it has a problem with other industry. According to Crafts and Harley, this part of industry had low productivity, contrasting with progressive British agriculture. As shown in Table 1 , the rate of productivity gain in services and other industry was lower than in agriculture. Unless other manufacturing started out from a position of great comparative advantage--a presumption belied by the abundant historical evidence of the eighteenth century--the ability to export other manufacturing would have been rapidly eroded by technical progress in cotton, iron, and even agriculture.

If agricultural goods were imported in the early nineteenth century, therefore, then other manufactures should have been as well. Harley's assumption that other manufacturing was not traded therefore is inappropriate. It allowed Harley to close his model, but it did not confront the problem of other manufactures. It swept it under the non-traded rug. Harley's model cannot demonstrate the consistency of the Crafts-Harley view.

In the literature survey noted above, O'Brien rather paradoxically criticized the crafts and Harley estimates as if 
he were supporting "old-hat" economic history. Noting that lack of data precludes universal coverage of any index, O'Brien stated: "Major industries (shipbuilding, chemicals, pottery, glass, furniture, most preserved foods, finished metallurgy and clothing) cannot be included because we lack data, while numerous sub-sectors of included industries are presumed to grow at the same rate as a single 'representative indicator' for an entire industry." 24

He seemed to conclude that the gap between "old-hat" and new-fangled economic history can never be bridged. The problem is that the data needed to construct national income aggregates do not exist for many parts of British industry in the early nineteenth century. Microeconomic and macroeconomic studies, O'Brien appeared to assert, will just have to go their own ways.

Instead of banging our head against the stone wall of unavailable data, I propose to shift the terms of debate to a different kind of data. ${ }^{25}$ Crafts and Harley have suggested some implications of the new view for Britain's international trade. Trade data are available in great detail; can they help us to disentangle the nature of the Industrial Revolution?

II

The implications of the Crafts and Harley view for Britain's international trade can be used to formulate a test of these views. A model is needed to derive a test, more formal than Crafts' verbal exposition and more transparent than Harley's computable general equilibrium model. The Ricardian 
model of international trade with many goods poses the issues clearly.

The Ricardian model of comparative advantage in international trade is now almost two centuries old. The most usual form of the model follows Ricardo in analyzing two, or very close to two, goods. This will not help us here when we are inquiring into the role of many goods just out of sight of other observations. We need a Ricardian model of trade with many goods.

A Ricardian model with many goods was analyzed by Dornbusch, Fischer and Samuelson, and I follow their exposition here. ${ }^{26}$ They argued that the many goods can be seen as spread out along a continuum of comparative advantage and dealt with by their location along this continuum. The historical application of this model will be to identify the location of specific goods in this continuum.

Imagine two "countries": Britain and everywhere else. For ease of exposition, I will refer to the rest of the world as if it were a single foreign country. Since this is a Ricardian model, there is only one factor of production: Labor. ${ }^{27}$ Each country both produces and consumes a large variety of goods made from this single factor of production. These goods can be numbered from 1 to $\mathrm{N}$.

The technology of each country can be described by the labor needed to produce each good. The labor requirement to produce the nth good in Britain is $a_{n}$, where $a_{n}$ is the number of 
hours of British labor needed to produce a single unit of the nth good. Following the convention of international trade, $a^{*}{ }_{n}$ represents the hours of foreign labor needed to produce the nth good in the foreign country.

Now it is possible to calculate for each good the ratio of the labor needed to produce the good in the foreign country and in Britain, that is $a{ }_{n} / a_{n}$. The goods can be re-indexed by this ratio, starting with the good for which the relative quantity of foreign labor needed for production is the highest (so the ratio, $a *_{n} / a_{n}$, is the highest).

$$
a{ }_{1} / a_{1}>a{ }_{2} / a_{2}>a{ }_{3} / a_{3}>\ldots .>a{ }_{N} / a_{N} .
$$

The pattern of trade is determined by the relative costs of producing goods in the two countries. And in this Ricardian model costs are simply the wages of the sole factor of production, labor. Let $w$ be the British wage; $w^{*}$, be the foreign wage. Then the cost of producing good $i$ in Britain is $w_{i} ;$ the cost in the foreign country, $w^{*} a^{*}{ }_{i}$. Any good for which $w^{*} a^{*}{ }_{i}>w_{i}$ will be produced in Britain because it production costs are cheaper in Britain.

This inequality can be rewritten as $a^{*}{ }_{i} / a_{i}>w / w^{*}$. Production costs for good this good are lower in Britain; the good will be produced in Britain and exported to the foreign country. Conversely, any good, $j$, for which $a^{*}{ }_{j} / a_{j}<w / w^{*}$ will be produced in the foreign country and imported into Britain. The numbering scheme for goods ensures that there is a point in the ordered list of goods such that all goods to the left with 
lower numbers are produced in Britain. All the goods with higher numbers are produced abroad. This is illustrated in Figure 1.

The exposition so far has taken the relative wage, $w / w^{*}$ as given. It needs only a small step to incorporate wage determination into the model. Assume that the supply of labor in each country is fixed. Then the wage is determined by the demand for labor. The two demand curves each will be downward sloping because a rise in, say, the British wage will cause some goods previously produced in Britain to be produced abroad and the demand for British labor to decline as a result. The equilibrium relative wage clearly depends on the relative costs of production in the two countries.

The model is complete at this point, but a few extensions are needed for a historical application. First, British trade was not balanced, except possibly briefly as she moved from being a capital importer in the eighteenth century to a capital exporter in the nineteenth. ${ }^{28}$

A rise in capital exports in any one year was associated with an equal rise in the trade balance. (Without more analysis, the direction of causation cannot be determined.) But the trade balance worsened in the decades before 1850 while capital exports did not increase. ${ }^{29}$ The trade balance was not constrained to be zero, nor was it controlled solely by capital exports. I assume the trade balance can be taken as exogenous over the course of decades, even if not from year to year. 
The deficit in Britain's balance of commodity trade was more than offset by a surplus in the export of freights, commissions, interest, and other services. ${ }^{30}$ Traded services-other than transport--present a complex problem of modeling. In the conditions of the early nineteenth century, it is reasonable to agree with Harley that trade barriers of various sorts precluded international trade in many services, whatever the costs of production. But as just noted, Britain exported various financial and trade-related services in significant quantities. These exports can be thought of as part of cotton exports, or the list of commodities in international trade can be expanded to goods and services. I ignore trade-related services here, both because the literature concentrates on commodity trade and because there are no data on gross flows.

In addition, the second extension, the model has assumed no transport or other costs of international trade. To remedy this failing, assume there are transport costs. They can be modelled with the Samuelson "iceberg" model, where transport costs take the form of shrinkage in transit so that only a fraction, $g$, of goods shipped arrive at their destination. (Transport costs are assumed equal for all goods for simplicity.) The conditions for British and foreign production now need to be modified.

As a result of transport costs, $w^{*} a^{*}{ }_{i}$ no longer represents the cost of one unit of the foreign good in Britain; it is the cost of only g unit. (Recall that $g<1$.) The cost of one unit of imports is $(1 / \mathrm{g}) \mathrm{w}^{*} \mathrm{a}^{*}{ }_{i}$. A good, $i$, therefore will be produced 
in Britain if $(1 / g) a^{*}{ }_{i} / a_{i}>w / w^{*}$, when the cost of importing the good is larger than the cost of producing it in Britain. Conversely, any good, $j$, for which $g a^{*} / a_{j}<w / w^{*}$ will be produced in the foreign country because the cost of importing the good to the foreign country, $(1 / g) w_{j} a_{j}$, is larger than the cost of production in the foreign country.

There now will be goods in the middle for which neither inequality is satisfied. Those goods will not be traded; they will be produced in both countries. The existence of transport costs creates a wedge into the comparison of production costs that changes the cut in the continuum of goods into a region of goods that are neither imported nor exported. Formally, a good, $k$, will be non-traded if:

$$
(1 / g) a^{*}{ }_{k} / a_{k}>w / w^{*}>g\left(a{ }_{k} / a_{k}\right) \text {. }
$$

These inequalities are illustrated in Figure 2. The first inequality shows the good is produced in Britain; the second, in the foreign country.

A uniform tariff has roughly the same effect in this model as transport costs. Tariffs on particular goods by contrast can affect the direction of trade. I ignore tariffs here on two grounds. British, American and French tariffs were falling in the first half of the nineteenth century. ${ }^{31}$ In addition, the pattern of trade to be described below does not vary enough to suggest that tariffs played much role in determining which goods were imports and which exports.

The third extension needed is to allow for technical change 
in Britain. There are two subcases. If the technical change is general, that is, it reduces $a_{i}$ for all $i$, then it will increase $a{ }^{*} / a_{1}$ for all $i$. The curve in Figure 1 will shift upward, increasing the range of goods exported by Britain at the same relative wage. It will move the point dividing imports and exports in expression (1) to the right. This in turn will increase the demand for labor in Britain and reduce the demand for labor in the foreign country. British wages consequently will rise relative to wages in the foreign country. A new equilibrium will be reached in which the range of British goods exported has increased, albeit not as much as in the original calculation.

It is worth noting that while technical change in Britain improves the British relative position, it increases real wages in both countries. Even foreign workers benefit from the British technical change because they now can get British goods cheaper than before. This elementary aspect of international trade often is forgotten in modern discussions of "competitiveness. " 32

If, by contrast, technical change is restricted to a few goods, the picture is more complex. This change does not initially move the boundary in the distribution of goods between imported and exported goods (or between imports and non-traded goods). It moves the goods experiencing technical change in the distribution of goods. Since nothing has changed in the foreign country by assumption, $a{ }_{i} / a_{i}$ has risen for those goods 
experiencing technical change, and these goods have moved to the left in expression (1).

If the goods experiencing technical change were non-traded or imported, they may become exports. As the exports of the goods experiencing technical change increase, the imports of other goods must increase to balance trade. The point dividing exports from imports (or non-traded goods) moves to the left in expression (1). ${ }^{33}$

Real wages will rise in this case too. Wages will rise in Britain because workers have become more productive, albeit only in a few industries. These industries will raise their wages and expand their production. Other industries will contract to the point where they break even with the new, higher wages. Real wages will rise in the foreign country because these imports will be cheaper.

Conversely, if a British sector has negative technical change--that is, if it stagnates while the rest of the economy progresses--then it will move to the right in the array. Depending on its starting point and the extent of its technical lag, it could cross a dividing line in Figure 2 and change from export to on-traded or import.

This discussion has shown that the two kinds of technical change have opposite implications for the movement of dividing points in expression (2). General technical change moves the dividing line between exports and non-traded goods to the right; restricted technical change, to the left. General technical 
change causes the list of exports to rise, while restricted technical change causes it to fall. This difference provides a test of historical views.

To create this test we need to identify the goods in the array of expression (2). There are three categories of goods in the extended model in expression (2) and Figure 2. From the British point of view, they are exports, non-traded goods, and imports. Following Harley, we can identify exports with modern British industry, non-traded goods with services not related to trade, and imports with agriculture. But Harley has a fourth good in his model which is of great interest here. The question is where to put Harley's fourth category, other manufactures. The discussion of the preceding section implies that there are two different answers. In the broad view of the Industrial Revolution, other manufactures were similar to modern manufactures; technical change was widespread. Exports of many manufactured goods should have been expanding. In the narrow view, by contrast, other manufactures were doing far worse than agriculture. Harley assumed they were not traded in his computable general equilibrium model, but as not above, this is implausible. Other manufactures should have been imports in the Crafts-Harley view of the economy.

There are two possible reasons why the Crafts-Harley view implies other manufactures were imports. As cotton changed from an import to an export in the eighteenth century, the range of other manufactures exported should have fallen. ${ }^{34}$ As technical 
progress in the residual sectors stagnated relative to agriculture in the nineteenth century, their costs of production in Britain should have risen sharply relative to the cost of growing food in Britain. Since agricultural goods were imported, the products of these other sectors--to the extent that they were traded at all--should have been imported as well. Even if other manufactures were not imported at the start of the century, the rates of productivity change shown in the last column of Table 1 surely would have made them imports by midcentury .

The Ricardian model consequently generates a simple test to discriminate between these two views. Were other manufacturers exported or imported? If exported, then the view that technical change was widespread among British industries in the early nineteenth century is confirmed. But if the other manufactures were imported, then the conclusion that technical change was restricted to a very few modern industries while other industries stayed mired in pre-modern production techniques is confirmed.

The path of trade in other manufactures also gives information. In the Crafts-Harley view shown in the last column of Table 1, these activities were not experiencing technical change in the first half of the nineteenth century. The productivity gap between other manufactures and agriculture--not to mention modern industry--was growing rapidly. Other manufactures, even if exported early in the Industrial 
Revolution, should have found their relative costs rising and their exports falling. They should have gone from exports to imports.

The traditional view, by contrast, maintains that technical change was endemic in British manufacturing. Industries other than cotton and iron benefited from lower costs. Their exports, albeit smaller than cotton, should have continued to grow during the first half of the nineteenth century.

The two views of the Industrial Revolution therefore can be tested by looking at marginal British exports. Were other manufactures exported as Ashton and Landes seem to imply or imported as Crafts and Harley imply? Was Britain losing manufacturing exports at the margin or gaining them?

It may seem odd to test major views of the Industrial Revolution by looking at marginal activities. Not only should major historical events have large causes, but the tests about them--it seems--should involve the principal activities as well. Unhappily, this is not the case. Different stories have been presented to explain the same events. To be plausible, they all have to explain the major aspects of these events. It is only in the details that they differ, although--as described above-these differences may imply other, more important disagreements. The devil, as they say, is in the details. ${ }^{35}$

\section{III}

British trade data can be found in various reports reproduced in the Parliamentary Papers. Davis analyzed these 
data and presented them in a uniform format. ${ }^{36}$ His results can be summarized for my purposes as shown in Table 2. Each entry shows a three-year average centered on the middle of the decade. (Davis also surveyed intermediate decades, with results close to those shown in Table 2.)

The dominant place of manufactures in British exports is easily apparent from the first row of Table 2. There is no dispute that in general Britain exported manufactures and imported raw materials and foodstuffs. The important and growing share of cotton manufactures in total manufactures is clear from the next row. It is worth noting that the large but falling share of woollens makes the share of cotton and woollen textiles stay more constant than either of them alone. Iron manufactures, for all their importance in the narratives of the Industrial Revolution, were never a major part of British manufacturing exports.

The question here is what was happening outside of these dominant industries. Davis identified a few other industries, but he generally aggregated industries other than the main categories. His data contain a large other manufacturing component. manufacturing exports other than cotton, woolens and iron, are shown in the last row of Table 2 . They were quite substantial, and they show no evidence of being pushed aside by cotton exports--as woolens were.

Davis' data suggest an answer to the questions posed above; exports of other manufacturing continued to grow throughout the 
Industrial Revolution. But there are several questions that need to be answered to provide a clear resolution. What was the composition of these other industries? Was Britain a net exporter of these goods, or did she import more of them than she exported? Did Britain continue to be a net exporter of other manufactures?

I went back to the original sources in the Parliamentary Papers to find data on exports of individual commodities. Not every year contained trade information in detail. I consequently had to chose years for which I found detailed data, which did not always correspond to the years Davis had surveyed. The trends shown in Table 2 were very clear in my data as well, and I do not think any information was lost in the change of dates.

Table 3, A-C, shows exports of other manufactures for three years centered on 1812,1831 , and 1851. The table lists all manufacturing exports other than those identified in Table 2 . They are sorted by the magnitude of exports in each period.

Linen was a major export. Silk manufactures also were steadily exported. Turning to metals, we find hardware and cutlery, brass and copper manufactures, and tin and pewter continuing to be exported. Other exports include earthenware, haberdashery, apparel, soap and hats. The interest of this list is the absence of an organizing principle. These are exports of many different sorts.

There is a suspicion that the composition of other exports 
changed more in the two decades before 1831 than after. The evidence does not confirm this view, however. Taking categories that existed in both years, the correlation between the first and second years shown is .93 (28 observations) and between the second and third, .95 (18 observations). ${ }^{37}$ Breaking up the earlier period--critical years in both the Industrial Revolution and the conversion to a peacetime economy--into subperiods gives the results shown in Table 4 . With the possible exception of the initial years of peace, there is no evidence of much change in the structure of other exports.

Before concluding that much of other British industry was not backward, we need to look at British imports. For if it turns out that these same articles were being imported, and especially if they were being imported in greater quantities than they were exported, the conclusion would not follow.

Table 5, A-C, shows the composition of British imports in. the same years as Table 3 . Tables $5 \mathrm{~A}$ and $5 \mathrm{~B}$ include all categories accounting from more than one per cent of imports in that year, sorted--as in Table 3--by the size of the imports. Many of the manufactured goods listed as exports in Table 3 were exported in smaller quantities than shown in Tables $5 \mathrm{~A}-\mathrm{B}$. I therefore provide a complete list of imports in Table $5 \mathrm{C}$.

Table 5C lists imports at the end of the period examined here, close to the end of the period of the calculations shown in Table 1. The effect of stagnating productivity outside the modern sector and agriculture should have been most evident 
around 1850. There is, as noted for exports in Table 4, little variation in the composition of British imports over the first half of the nineteenth century.

It can be seen easily that the imports are not of the same goods that were being exported, with a few exceptions. Silk was imported in greater quantities than it was exported. This was not an activity in which Britain maintained a comparative advantage. Linen was imported in 1811-3, and Davis' data show that linen continued to be imported through the mid-1820s. But then linen imports virtually ceased. ${ }^{38}$ (Very small imports of linen can be seen in Table 5C.) The substantial imports that continued were of flax. The manufacture of linen from flax continued to be a successful British export throughout the Industrial Revolution.

It is not surprising, of course, that Britain imported sugar, tea, or indigo. They, and the many other tropical products consumed in Britain, would not have been imported under any reasonable set of prices or changes in productivity. The important agricultural imports for the test performed here are corn, hides and wool (sheep's). They were imported from Northern and North-western Europe and could have been exported from Britain. ${ }^{39}$ These products are the products that Britain should have exported before other manufactures in the nineteenth century according to the Crafts-Harley view.

None of the myriad other British manufacturing exports were imported at all. Britain maintained a clear comparative 
advantage in a wide variety of manufacturing industries throughout the first half of the nineteenth century. They held their own in the face of the spectacular growth of cotton textile exports during those years. There is no hint that these other commodities were being pushed off the list of exports by the growth of cotton exports. Except for the Napoleonic War period, they kept pace with cotton exports.

There is an exception that proves the rule. Table $5 \mathrm{C}$ shows that there were small imports of manufactured woolens and cotton. But they were approximately one-tenth the amounts of the exports of those commodities shown in Table 2.40 They are hardly the exception. Further down the list in Table $5 \mathrm{C}$ come watches and clocks. As David Landes noted in his book on that industry, the English clock and watch makers were falling behind their continental competitors in the nineteenth century. ${ }^{41}$ Productivity stagnated in this industry, and it had become an. import industry by mid-century. ${ }^{42}$ -

The export of most other manufactures, however, was growing as fast as cotton exports for much of the early nineteenth century. The lesson of the constant rank order of these exports is that the various industries listed were keeping pace with cotton textiles. The share of cotton textiles in total manufacturing exports peaked in the $1830 \mathrm{~s}$ as shown in Table 2 . There was a slight fall in the share from 1814-16 to 1854-56. Other exports kept pace with cotton exports during these forty years, and exports of individual industries did so as wel1. ${ }^{43}$ 
It follows therefore that the traditional, "old-hat" view of the Industrial Revolution is more accurate than the new, restricted image. Other British manufactures were not inefficient and stagnant, or at least, they were not all so backward. The spirit that motivated cotton manufactures extended also to activities as varied as hardware and haberdashery, arms and apparel.

It follows also that the calculations shown in the last column of Table 1 cannot be accepted as authoritative. The low rate of productivity change shown for other activities is too low. There must have been more technical progress outside the listed sectors in Table 1 to produce the results shown here. IV

This test confirms the traditional view that the Industrial Revolution saw changes in more than a few industries. Technical change was hardly uniform--a point conceded by every historian-but it was widespread. Britain became the workshop of the world, not just the cotton factory of the world.

Before we leave the field, however, we need to return to the traditional histories of the Industrial Revolution and ask if they described changes in the industries listed in Table 3. Is this a confirmation of the traditional view or the beginning of a new one?

Ashton described progress in the pottery industry, and McKendrick has shown that wedgwood introduced new forms of organization more than new technology. ${ }^{44}$ Landes described 
changes in the chemical industry, but sulfuric acid and sodium alkali do not seem to have been exported. ${ }^{45}$ In general these authors appealed to a more general change as noted above.

This pattern has been followed in more recent work. Maxine Berg, for example, asserted that, "There was substantial growth in a whole range of traditional industries as well as in the most obviously exciting cases of cotton and iron." But she confined her detailed work to cotton textiles and the metal trades. Her discussion of the Birmingham toy trades, however, may correspond to parts of the export classes of brass and copper manufactures. Buttons, also made in Birmingham, may have been part of haberdashery. ${ }^{46}$

For the rest, there are only isolated observations. Machine spinning was applied to flax by the 1820 s in Ulster and in Dundee, where there were 17 steam-powered flax mills employing 2,000 workers. ${ }^{47}$ Perhaps the products of these mills. drove imported linen from Britain by the end of the 1820s. Berg described the various metal trades in Birmingham and Sheffield in the 18th century, but she saw a "hiatus" in the 19 th. ${ }^{48}$ Mokyr included a miscellaneous category in his survey of technological change, but he did not isolate discoveries in Britain or assert that the varied progress he observed moved faster in Britain than on the Continent. ${ }^{49}$

These scattered descriptions suggest the existence of a pattern in these other manufactures. With few exceptions like linen, there were no factories like the famous cotton factories. 
Instead there were new organizations of work along the lines identified by Sabel and Zeitlin. ${ }^{50}$ "Flexible specialization" has been thought of as a description of French industrialization. ${ }^{51}$ Perhaps it also describes a significant part of the Industrial Revolution in Britain.

More research will be needed to confirm or refute suggestions like this. The test performed here shows that increases in British productivity were not confined to cotton and iron in the first half of the nineteenth century. The "oldhat" view of the Industrial Revolution cannot be banished by calling it names. It lives among us, and it deserves more attention to fill in its all too evident gaps. 
1. Ashton, The Industrial Revolution, p. 42 .

2. Mokyr, "Editor's Introduction," pp. 6-7, distinguishes four views of the Industrial Revolution. My division corresponds roughly to his macroeconomic and technological schools.

3. Cameron, A Concise Economic History, 165-67.

4. Ashton, The Industrial Revolution, pp. 13, 42 .

5. Ashton, The Industrial Revolution, p. 61 .

6. Ashton, The Industrial Revolution, p. 64.

7. Landes, Prometheus Unbound, pp. 41, 105.

8. Hartwell, The Industrial Revolution; Matthias, The First Industrial Nation; Deane, The First Industrial Revolution; Deane and Cole, British Economic Growth, 1688-1959.

9. Mokyr, The Lever of Riches, Chapter 10.

10. O'Brien, "Introduction," p. 7.

11. Harley, "British Industrialization before 1841"; Deane and Cole, British Economic Growth, 1688-1959; Crafts, British Economic Growth during the Industrial Revolution; Crafts, and Harley, "Output Growth and the Industrial Revolution."

12. McCloskey, "The Industrial Revolution: A Survey," p. 114.

13. Crafts, British Economic Growth, p. 86, emphasis in the original. Crafts' estimates reduced the implied rate of productivity change in all other sectors from .65 percent per year to .08 . He added in a footnote that even this new, low estimate could be an overestimate.

14. Crafts, "Industrial Revolution in Britain and France."

15. Landes, "What Room for Accident?"

16. Crafts, "Macroinventions"; Landes, "Some Further Thoughts."

17. Crafts concluded in his 1985 book that the British loss of industrial leadership in the late nineteenth century was a natural result of the narrowness of the Industrial Revolution. 
18. Crafts, "British Industrialization in an International context."

19. Crafts, "British Industrialization in an International Context," p. 425.

20. Crafts and Harley, "Output Growth and the Industrial Revolution."

21. Harley, "Reassessing the Industrial Revolution," p. 200. The modernized sector and agriculture were about the same size, and their relative rates of productivity gain mirror their relative contributions. The residual sector was about three times as large, and its implied rate of growth therefore was only one-third as large as it might seem from a comparison with the contributions of the other sectors.

22. McCloskey, "The Industrial Revolution," p. 114.

23. Harley, "Reassessing the Industrial Revolution."

24. O'Brien, "Introduction," p. 13.

25. Berg and Hudson, "Rehabilitating the Industrial Revolution," also recommend shifting the terms of debate about the Industrial Revolution, albeit in a different direction than developed here.

26. Dornbusch, Fischer and Samuelson, "Comparative Advantage."

27. This model does not abstract from the existence of multiple factors of production, but only from changes in the relative prices of factors of production. My argument is that productivity change overwhelmed variations in factor prices in determining the pattern of British trade considered here.

28. Brezis, "Foreign Capital Flows."

29. Data from Imlah, Economic Elements in the Pax Britannica, pp. 70-72. The regression, for 1816-50, is (with t-statistics):

$$
\text { TRADEBAL }=\text { CON }+\frac{1.1}{(5.1)} \text { CAPEXPORT }-5.0 \text { YEAR }
$$

The $R^{2}=.69$. The effect of lagged capital exports was not significantly different from zero.

30. Imlah, Economic Elements in the Pax Britannica, pp. 47-56.

31. Nye, "The Myth of Free-Trade Britain." 
32. Thurow, Head to Head; Krugman, Peddling Prosperity.

33. This statement is not quite straightforward because the ordering of the goods has changed. It applies to the list of all those goods not experiencing technical change for which the ordering also has not changed.

34. Ashton, An Economic History of Britain, p. 154; Cameron, $\underline{A}$ Concise Economic History, p. 160.

35. This is the same argument I used in a very different context in Did Monetary Forces Cause the Great Depression?

36. Davis, The Industrial Revolution and British Overseas Trade.

37. The 1811-13 data are in official values, while the later data are in real values. This does not seem to have affected the correlation, but it is hard to know. There also are fewer observations in the 1811-13 data because fewer individual exports are identified.

38. Davis, The Industrial Revolution and British overseas Trade, pp. $118-20$.

39. Davis, The Industrial Revolution and British Overseas Trade, pp. $114-24$.

40. Davis, The Industrial Revolution and British overseas Trade, p. 101 .

41. Landes, Revolution in Time.

42. The data underlying Tables $5 \mathrm{~A}-\mathrm{B}$ show that clocks and watches were not imported earlier in the nineteenth century.

43. It would of course be nice to extend this story back into the eighteenth century. Three problems get in the way. The wars and the Continental System, as mentioned above, distorted trade. The use of official values for exports distorted the data. And the Parliamentary Papers for the earlier period did not contain the same level of detail.

44. McKendrick, "Josiah Wedgwood."

45. Landes, Prometheus Unbound, pp. 109-12. Presumably high costs of transport precluded an export trade.

46. Berg, The Age of Manufactures, p. 316 and Chap. 12 . 
47. Berg, The Age of Manufactures, p. 226; Collins, "The Organization of Sewing Outwork," p. 140.

48. Berg, "Small Producer Capitalism."

49. Mokyr, The Lever of Riches, pp. 103-12.

50. Sabel and Zeitlin, "Historical Alternatives to Mass Production."

51. Piore and Sabel, The Second Industrial Divide. 
Figure 1

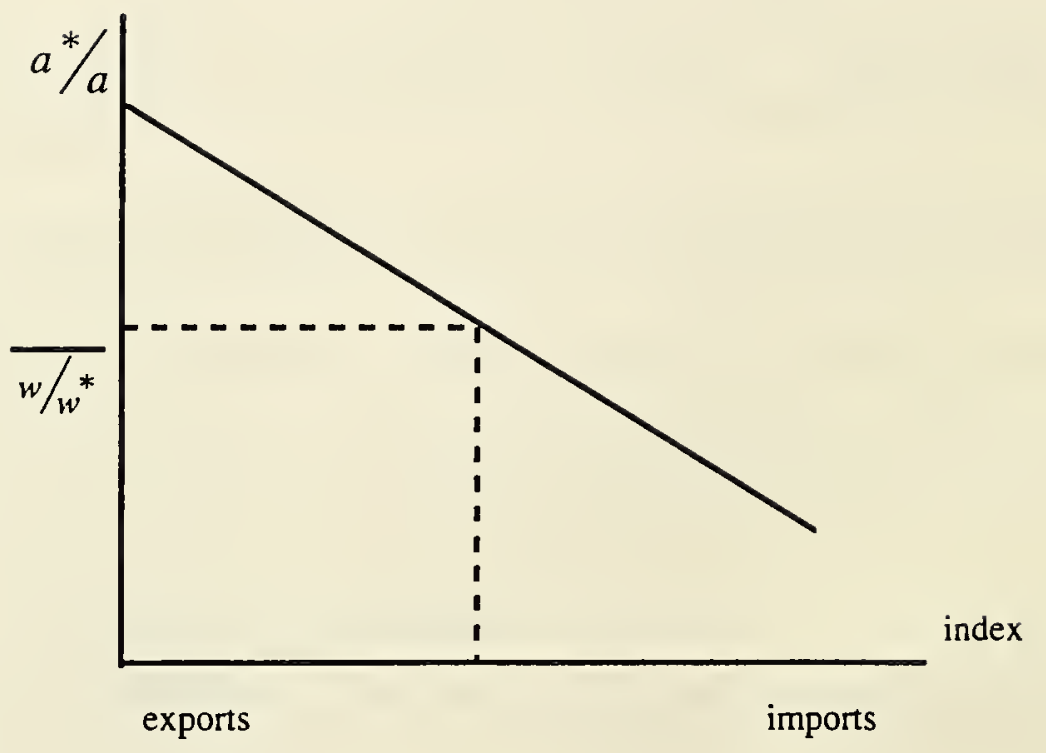


Figure 2

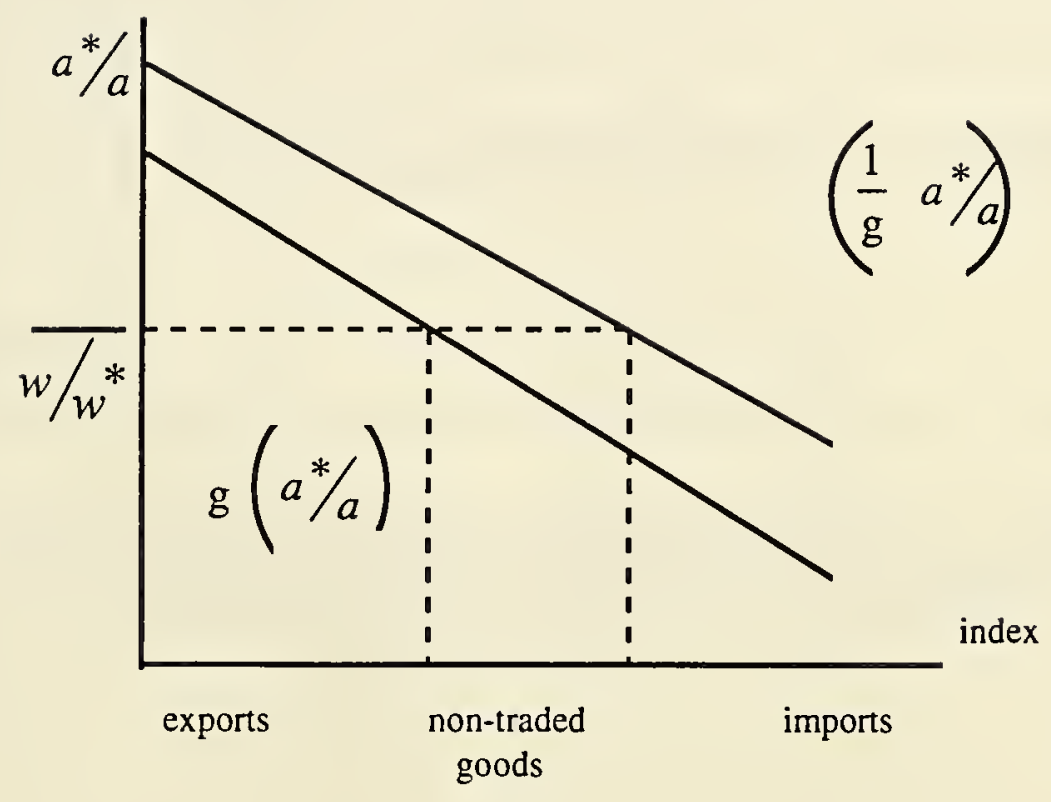


Table 1

Contributions to National Productivity Growth $1780-1860$

(per cent per annum)

\begin{tabular}{||l|c|c|c||}
\hline \multicolumn{1}{|c|}{ Sector } & McCloskey & Crafts & Harley \\
\hline \hline Cotton & .18 & .18 & .13 \\
\hline Worsteds & .06 & .06 & .05 \\
\hline Woolens & .03 & .03 & .02 \\
\hline Iron & .02 & .02 & .02 \\
\hline Canals and Railroads & .09 & .09 & .09 \\
\hline Shipping & .14 & .14 & .03 \\
\hline Sum of Modernized & .52 & .52 & .34 \\
\hline Agriculture & .12 & .12 & .19 \\
\hline All Others & .55 & .07 & .02 \\
\hline Total & 1.19 & .71 & .55 \\
\hline
\end{tabular}

Sources: McCloskey, "The Industrial Revolution," p. 114; Crafts, British Economic Growth during the Industrial Revolution, p. 86; Harley, "Reassessing the Industrial Revolution," p. 200. 
Table 2

Shares of Total and Manufacturing Exports (per cent)

\begin{tabular}{||l|c|c|c|c||}
\hline & $1794-96$ & $1814-16$ & $1834-36$ & $1854-56$ \\
\hline Manufacturing/Total & 86 & 82 & 91 & 81 \\
\hline Cotton/Manufacturing & 18 & 49 & 53 & 42 \\
\hline Woolens/Manufacturing & 27 & 21 & 17 & 15 \\
\hline Iron/Manufacturing & 11 & 2 & 2 & 7 \\
\hline Other/Manufacturing & 44 & 28 & 28 & 36 \\
\hline
\end{tabular}

Source: Davis, The Industrial Revolution and British Overseas Trade, pp. 95-101. 
Table 3A

Exports of Other Manufactures, 1811-13

(Pounds Sterling)

\begin{tabular}{|c|c|}
\hline Linens & 853,673 \\
\hline Brass and Copper & 346,954 \\
\hline Hats & 275,130 \\
\hline Apparel & 234,521 \\
\hline Glass and Earthenware & 210,104 \\
\hline $\begin{array}{l}\text { Stationary/Stationery of all } \\
\text { sorts }\end{array}$ & 205,205 \\
\hline Tin and Pewter & 202,945 \\
\hline $\begin{array}{l}\text { Colours for Painters/Painters' } \\
\text { Colours }\end{array}$ & 166,071 \\
\hline Silks & 164,256 \\
\hline $\begin{array}{l}\text { Plate, Plated Ware, and } \\
\text { Jewellery }\end{array}$ & 148,930 \\
\hline Soap and Candles & 99,573 \\
\hline Lead and Shot & 98,589 \\
\hline Cabinet and Upholstery Wares & 88,232 \\
\hline Cordage & 64,775 \\
\hline Beer & 63,796 \\
\hline Musical Instruments & 53,181 \\
\hline Haberdashery & 48,734 \\
\hline Guns & 43,803 \\
\hline Gunpowder & 21,505 \\
\hline
\end{tabular}

Source: Parliamentary Papers, 1812-13 (100)XI.1 
Table 3B

Exports of Other Manufactures, 1830-32

(Pounds sterling)

\begin{tabular}{|c|c|}
\hline Linens & $1,998,832$ \\
\hline Hardwares and Cutlery & $1,473,563$ \\
\hline Brass and Copper Manufactures & 825,611 \\
\hline Silk Manufactures & 455,124 \\
\hline Earthenware of all sorts & 453,414 \\
\hline Glass/Glass of all sorts & 429,216 \\
\hline Haberdashery and Millinery & 397,954 \\
\hline Apparel, Slops and Negro Clothing & 380,151 \\
\hline Arms and Ammunition & 361,245 \\
\hline Tin and Pewter Wares and Tin Plates & 238,215 \\
\hline Soap and Candles & 207,742 \\
\hline Beer and Ale & 201,881 \\
\hline Hats, Beaver and Felt & 188,826 \\
\hline Machinery and Mill-work & 188,101 \\
\hline $\begin{array}{l}\text { Plate, Plated Ware, Jewellery and } \\
\text { Watches }\end{array}$ & 185,127 \\
\hline Stationary/stationery of all sorts & 177,605 \\
\hline $\begin{array}{l}\text { Colours for Painters/Painters' } \\
\text { Colours }\end{array}$ & 110,931 \\
\hline Lead and Shot & 105,836 \\
\hline Books, Printed & 101,352 \\
\hline Cordage & 84,269 \\
\hline Leather Saddlery and Harness & 74,006 \\
\hline Cabinet and Upholstery Wares & 52,508 \\
\hline Musical Instruments & 49,629 \\
\hline Umbrellas and Parasols & 38,445 \\
\hline Mathematical and Optical Instruments & 20,054 \\
\hline Tobacco (Manufactured) and Snuff & 17,957 \\
\hline Hats of all other sorts & 15,629 \\
\hline Bread and Biscuit & 10,009 \\
\hline Spirits & 5,766 \\
\hline
\end{tabular}

Source: Parliamentary Papers, 1831-32 (310)XXVI.I 
Table 3C

Exports of Other Manufactures, 1850-52 (Pounds Sterling)

\begin{tabular}{|c|c|}
\hline Linens & $4,694,567$ \\
\hline Hardwares and Cutlery & $2,556,441$ \\
\hline Brass and Copper Manufactures & $1,830,793$ \\
\hline Haberdashery and Millinery & $1,463,191$ \\
\hline Silk Manufactures & $1,193,537$ \\
\hline Earthenware of all sorts & 975.855 \\
\hline Machinery and Mill-work & 970,077 \\
\hline Tin and Pewter Wares and Tin Plates & 904,275 \\
\hline Apparel, Slops and Negro Clothing & 892,105 \\
\hline Beer and Ale & 513,044 \\
\hline Arms and Ammunition & 505,096 \\
\hline Stationary/stationery of all sorts & 373,987 \\
\hline Apothecary Wares & 354,962 \\
\hline Lead and Shot & 339,773 \\
\hline Glass/Glass of all sorts & 296,331 \\
\hline $\begin{array}{l}\text { Plate, Plated Ware, Jewellery and } \\
\text { Watches }\end{array}$ & 286,738 \\
\hline Soap and Candles & 275,200 \\
\hline Painters' Coulours and Materials & 237,880 \\
\hline Books, Printed & 234,190 \\
\hline Cabinet and Upholstery Wares & 155,407 \\
\hline Cordage & 155,127 \\
\hline Leather Saddlery and Harness & 121,401 \\
\hline Hats of all other sorts & 106,933 \\
\hline Musical Instruments & 85,006 \\
\hline Umbrellas and Parasols & 72,928 \\
\hline Carriages of all sorts & 57,018 \\
\hline Spirits & 52,843 \\
\hline Fishing Tackles & 41,607 \\
\hline Hats, Beaver and Felt & 34,351 \\
\hline Mathematical and Optical Instruments & 34,289 \\
\hline Spelter, Wrought and Unwrought & 22,097 \\
\hline Bread and Biscuit & 15,529 \\
\hline Tobacco (Manufactured) and Snuff & 14,762 \\
\hline
\end{tabular}

Source: Parliamentary Papers, 1852 (196)XXVIII.1 
Table 4

Correlations Among Other Manufacturing Exports

\begin{tabular}{||c|c|c||}
\hline Years & $\begin{array}{c}\text { Nbr. of } \\
\text { Observations }\end{array}$ & Correlation \\
\hline \hline $1811-13$ and $1816-18$ & 15 & .78 \\
\hline $1816-18$ and $1821-23$ & 21 & .90 \\
\hline $1821-23$ and $1826-28$ & 21 & .97 \\
\hline $1826-28$ and $1830-32$ & 28 & .98 \\
\hline
\end{tabular}

Source: Parliamentary Papers, 1812-13 (100)XI.1, 1818 (147)XII.1, 1823 (220)XII.1, 1828 (130)XVI.1, 1831-32 (310)XXVI.1. 
Table 5A

Principal Imports, 1811-13

(Pounds Sterling)

\begin{tabular}{||l|c|}
\hline \hline Sugar & $5,660,411$ \\
\hline Coffee & $3,911,934$ \\
\hline Wool, Cotton & $3,428,358$ \\
\hline Tea & $2,040,930$ \\
\hline Wood & $1,199,053$ \\
\hline $\begin{array}{l}\text { Corn, Grain, Meal, and } \\
\text { Rice }\end{array}$ & $1,182,036$ \\
\hline Wines & 819,952 \\
\hline Silk & 817,277 \\
\hline Indigo & 736,609 \\
\hline Spirits & 675,450 \\
\hline Flax, Rough & 643,301 \\
\hline Hemp, Rough & 562,618 \\
\hline Piece Goods & 524,146 \\
\hline Hides, Raw and Tanned & 433,964 \\
\hline Oil & 426,216 \\
\hline Wool, Sheep's & 415,742 \\
\hline Linens (Foreign) & 399,874 \\
\hline Tallow & 382,467 \\
\hline Tobacco & 321,689 \\
\hline \hline
\end{tabular}

Source: Parliamentary Papers, 1812-13 (100)XI.1 
Table 5B

Principal Imports, 1830-32

(Pounds Sterling)

\begin{tabular}{||l|c|}
\hline Wool, Cotton & $8,508,501$ \\
\hline Sugar & $6,532,557$ \\
\hline $\begin{array}{l}\text { Corn, Grain, Meal, and } \\
\text { Flour }\end{array}$ & $3,814,177$ \\
\hline Tea & $3,136,369$ \\
\hline Silk & $2,664,562$ \\
\hline Coffee & $2,521,837$ \\
\hline $\begin{array}{l}\text { Flax and Tow or Codilla } \\
\text { of Hemp and Flax }\end{array}$ & $1,872,458$ \\
\hline Tallow & $1,094,897$ \\
\hline Oil & $1,009,906$ \\
\hline Indigo & 993,610 \\
\hline Hides, Raw and Tanned & 868,532 \\
\hline Spirits & 866,953 \\
\hline Wool, Sheep's & 829,802 \\
\hline Wines & 753,795 \\
\hline Timber & 636,487 \\
\hline Madder and Madder Roots & 443,393 \\
\hline \hline
\end{tabular}

Source: Parliamentary Papers, 1831-32 (310)XXVI.1 
Table 5c: Imports, 1850-52 (Pounds Sterling)

\begin{tabular}{|c|c|}
\hline Wool, cotton & $23,670,472$ \\
\hline Sugar & $10,762,045$ \\
\hline Corn, Meal and Flour & $9,167,600$ \\
\hline Tea & $5,796,086$ \\
\hline Silk & $5,163,865$ \\
\hline Coffee & $3,480,594$ \\
\hline Flax, and Tow or Codilla of Hemp and Flax & $3,123,329$ \\
\hline Wool, Sheep's & $2,049,348$ \\
\hline Hides, Raw or Tanned & $1,999,233$ \\
\hline Cochineal, Granilla and Dust & $1,909,848$ \\
\hline Oil & $1,793,320$ \\
\hline Madder, Madder Root, and Garancine & $1,687,568$ \\
\hline Guano & $1,476,940$ \\
\hline Tallow & $1,333,889$ \\
\hline Indigo & $1,191,495$ \\
\hline Wood and Timber & $1,153,477$ \\
\hline Dye and Hardwoods & $1,104,308$ \\
\hline Hemp, Dressed or Undressed & 990,917 \\
\hline Spelter & 957,540 \\
\hline Wines & $927,721^{\prime}$ \\
\hline Spirits & 902,351 \\
\hline Seeds & 719,017 \\
\hline Woollen Manufactures & 710,414 \\
\hline Rice cleaned, or in the Husk & 668,585 \\
\hline Bacon & 653,214 \\
\hline Potatoes & 562,595 \\
\hline Currants & 559,919 \\
\hline Cotton Manufactures & 548,065 \\
\hline Cheese & 537,322 \\
\hline Copper, Unwrought and part Wrought & 477,778 \\
\hline Butter & 466,357 \\
\hline Brimstone & 383,691 \\
\hline Tobacco and Snuff & 367,685 \\
\hline
\end{tabular}


Table 5c, continued

\begin{tabular}{|c|c|}
\hline Skins and Furs & 367,269 \\
\hline Saltpetre and Cubic Nitre & 355,564 \\
\hline Iron in Bars, Unwrought & 336,706 \\
\hline Gum & 298,147 \\
\hline Oil seed Cakes & 296,993 \\
\hline Glass & 270,110 \\
\hline Lard & 258,790 \\
\hline Ashes, Pearl and Pot & 238,077 \\
\hline Bark & 213,708 \\
\hline Turpentine & 213,561 \\
\hline Pork, Salted or Fresh & 210,692 \\
\hline Quicksilver & 201,669 \\
\hline $\operatorname{Tin}$ & 200,801 \\
\hline Sago & 178,329 \\
\hline Raisins & 170,443 \\
\hline Lead, Pig and Sheet & 169,024 \\
\hline Borax & 164,565 \\
\hline Terra Japonica and Cutch & 150,035 \\
\hline Hair or Goats' Wool, Manufactures of & 148,473 \\
\hline Cocoa, Cocoa-Nut Husks and Shells, and Chocolate & 145,973 \\
\hline Tar & 142,819 \\
\hline Bones of Animals and Fish (except Whale-fins) & 140,049 \\
\hline Cinnamon & 132,648 \\
\hline Beef, Salted or Fresh & 122,855 \\
\hline Embroidery and Needlework & 114,999 \\
\hline Copper Ore and Regulus & 113,166 \\
\hline Cloves & 106,630 \\
\hline Animals, living; viz. Oxen, Bulls, Cows and Calves & 103,463 \\
\hline Watches & 95,928 \\
\hline Safflower & 94,911 \\
\hline Boots, Shoes and Calashes, and Boot Fronts & 94,779 \\
\hline Pepper & 93,744 \\
\hline Lace, Thread, and Cushion or Pillow Lace & 82,816 \\
\hline
\end{tabular}


Table 5C, concluded

\begin{tabular}{|c|c|}
\hline Leather Gloves & 81,441 \\
\hline Shumac & 80,320 \\
\hline Oranges and Lemons & 74,845 \\
\hline Yarn, Worsted or Silk and Worsted & 73,690 \\
\hline Clocks & 73,661 \\
\hline Rhubarb & 70,912 \\
\hline Whalefins & 69,277 \\
\hline Valonia & 66,799 \\
\hline Hair, Horse & 63,159 \\
\hline Fish, of British taking & 60,405 \\
\hline Nutmegs & 60,144 \\
\hline Almonds of all sorts & 59,705 \\
\hline Linens & 57,562 \\
\hline Pimento & 57,222 \\
\hline Liquorice Juice and Paste & 54,153 \\
\hline Senna & 53,452 \\
\hline Cork & 53,196 \\
\hline Rags, \&C. for Paper & 49,140 \\
\hline Wax, Bees' & 46,160 \\
\hline Teeth, Elephants' & 44,661 \\
\hline Bristles & 44,048 \\
\hline Cassia Lignea & 43,735 \\
\hline Mace & 41,082 \\
\hline Ginger & 40,639 \\
\hline Animals, living; viz. Sheep and Lambs & 35,144 \\
\hline Books, Bound or Unbound & 33,865 \\
\hline Hams & 28,935 \\
\hline Annatto & 25,468 \\
\hline Isinglass & 24,685 \\
\hline Figs & 22,812 \\
\hline Barilla and Alkali & 2,122 \\
\hline
\end{tabular}

Source: Parliamentary Papers, 1852 (196)XXVIII.1 
Ashton, T. S., An Economic History of England: The 18th Century (London: Methuen, 1955).

Ashton, T. S., The Industrial Revolution (Oxford: Oxford University Press, 1971 [1948]).

Berg, Maxine, The Age of Manufactures: Industry, Innovation and Work in Britain, 1700-1820 (Ottawa, NJ: Banes and Noble, 1985).

Berg, Maxine, "Small Producer Capitalism in Eighteenth-Century England," Business History, 35: 17-39 (January 1993).

Berg, Maxine, and Pat Hudson, "Rehabilitating the Industrial Revolution," Economic History Review, 45: 24-50 (February 1992).

Brezis, Elide, "Foreign Capital Flows in the Century of Britain's Industrial Revolution: New Estimates, Controlled Conjectures," Economic History Review, 48: 46-67 (February 1995).

Cameron, Rondo, A Concise Economic History of the World from Paleolithic Times to the Present, 2nd ed. (Oxford: Oxford University Press, 1993.

Collins, Brando, "The Organization of Sewing Outwork in Late Nineteenth-Century Ulster," in Maxine Berg (ed.), Markets and Manufacture in Early Industrial Europe (London: Routledge, 1991), pp. 139-56.

Crafts, N. F. R. "Industrial Revolution in Britain and France: Some Thoughts on the Question 'Why was England First?' " Economic History Review, 30:429-41 (1977).

Crafts, N. F. R., British Economic Growth during the Industrial Revolution (Oxford: Clarendon Press, 1985).

Crafts, N. F. R., "British Industrialization in an International Context," Journal of Interdisciplinary History, 19: 415-28

(Winter 1989).

Crafts, N. F. R., "Macroinventions, Economic Growth, and 'Industrial Revolution' in Britain and France," Economic History Review, 48: 591-98 (August 1995).

Crafts, N. F. R., and C. K. Harley, "Output Growth and the Industrial Revolution: A Restatement of the Crafts-Harley View, " Economic History Review, 45: 703-30 (1992). 
Davis, Ralph, The Industrial Revolution and British Overseas Trade (Leicester: Leicester University Press, 1979).

Deane, Phyllis, The First Industrial Revolution (Cambridge: Cambridge University Press, 1965).

Deane, Phyllis, and W. A. Cole, British Economic Growth, 16881959 (Cambridge: Cambridge University Press, 1962);

Dornbusch, R., S. Fischer and P. Samuelson, "Comparative Advantage, Trade, and Payments in a Ricardian Model with a Continuum of Goods," American Economic Review, 67: 823-39 (December 1977).

Harley, C. Knick, "British Industrialization before 1841: Evidence of Slower Growth during the Industrial Revolution," Journal of Economic History, 42: 267-89 (1982);

Harley, C. Knick, "Reassessing the Industrial Revolution: A Macro View," in Joel Mokyr (ed.), The British Industrial Revolution: An Economic Perspective (Boulder, CO: Westview Press, 1993), pp. 171-226.

Hartwell, R, M, The Industrial Revolution and Economic Growth (London: Methuen, 1971).

Imlah, Albert H., Economic Elements in the Pax Britannica (Cambridge, MA: Harvard University Press, 1958.

Krugman, Paul, Peddling Prosperity: Sense and Nonsense in the Age of Diminished Expectations (New York: Norton, 1994).

Landes, David S., Prometheus Unbound: Technological Change and Industrial Development in Western Europe from 1750 to the present (Cambridge: Cambridge University Press, 1969).

Landes, David S., Revolution in Time: Clocks and the Making of the Modern World (Cambridge, MA: Harvard University Press, 1983).

Landes, David S., "What Room for Accident in History? Explaining Big Changes by Small Events," Economic History Review, 47: 63756 (November 1994).

Landes, David S., "Some Further Thoughts on Accident in History: A Reply to Professor Crafts," Economic History Review, 47: 599601 November 1994).

Matthias, Peter, The First Industrial Nation (London: Methuen, 1969). 


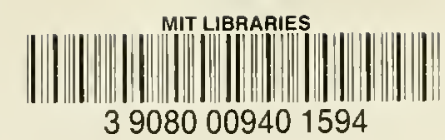

McCloskey, D. N., "The Industrial Revolution: A Survey," in R. C. Floud and D. N. McCloskey (eds.), The Economic History of Britain since 1700 (Cambridge: Cambridge University Press, 1981).

McKendrick, Neil, "Josiah Wedgwood: An Eighteenth-Century Entrepreneur in Salesmanship and Marketing Techniques, " Economic History Review, 12: (1960).

Mokyr, Joel, The Lever of Riches: Technological Creativity and Economic Progress (New York: Oxford University Press, 1990).

Mokyr, Joel, "Editor's Introduction: The New Economic History and the Industrial Revolution, "in Joel Mokyr (ed.), The British Industrial Revolution: An Economic Perspective (Boulder, $\mathrm{CO}$ : Westview Press, 1993), pp. 1-131.

Nye, John Vincent, "The Myth of Free-Trade Britain and Fortress France: Tariffs and Trade in the Nineteenth Century, " Journal of Economic History, 51: 23-46 (March 1991).

O'Brien, Patrick K., "Introduction: Modern Conceptions of the Industrial Revolution," in Patrick $\mathrm{K}$. O'Brien and Roland Quinault (eds.), The Industrial Revolution and British Society (Cambridge: Cambridge University Press, 1993), pp. 1-30.

Piore, Michael, and Charles Sabel, The Second Industrial Divide (New York: Free Press, 1984).

Sabel, Charles, and Jonathan Zeitlin, "Historical Alternatives to Mass Production: Politics, Markets, and Technology in Nineteenth-Century Industrialization," Past and Present, 108: 133-76 (1985).

Temin, Peter, Did Monetary Forces Cause the Great Depression? (New York: Norton, 1976).

Thurow, Lester, Head to Head: The Coming Economic Battle Among Japan, Europe, and America (New York: Morrow, 1992). 
2554.32 





14.

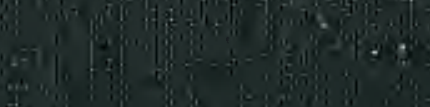

语

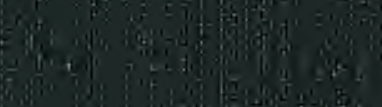

(1) and

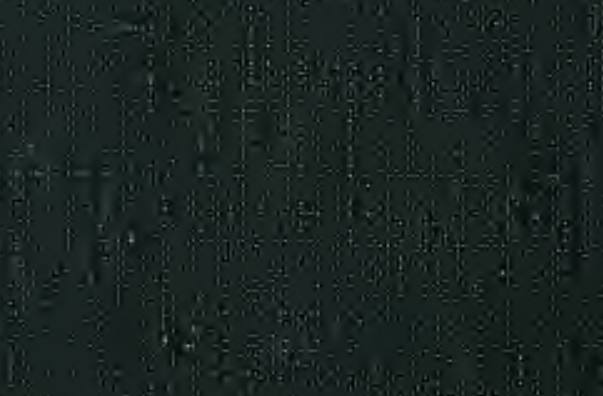

